\title{
Auditing Issues with Chinese Reverse Merger Companies Traded in the United States
}

\author{
Frederic M. Stiner, Jr., Ph.D., CPA (Corresponding author) \\ Visiting Professor, Department of Accounting \\ Merrick School of Business, University of Baltimore \\ 1420 N. Charles St., Baltimore MD 21201 USA. \\ Tel. 1-410-837-5114Ｅ-mail: fstiner@ubalt.edu \\ Susan A. Lynn, DBA, CPA \\ Associate Professor, Department of Accounting \\ Merrick School of Business, University of Baltimore, USA \\ Tel. 1-410-837-5099Ｅ-mail: slynn@ubalt.edu
}

Received: August 03, 2012 Accepted: September 20, 2012 DOI: 10.5296/ijafr.v2i2.2187

\begin{abstract}
Recently there have been two issues related to Chinese companies seeking capital in the United States. The first issue is frauds that have been perpetrated by companies using reverse mergers in order to go public. The second issue is fraud in continuing audit engagements when there has been reliance by an American audit firm on a foreign accountant's audit work. There is also conflict between the Public Company Accounting Oversight Board (PCAOB) demanding to inspect audit work papers for companies in China and the Chinese government's refusal to let the PCAOB see these work papers. These issues relate to characteristics of the practice of accounting and auditing in China that threaten auditor independence and audit quality. The paper discusses: (1) issues involving reverse mergers and the response of the Securities and Exchange Commission (SEC) to these issues, (2) issues involving reliance on the work of foreign Certified Public Accountants (CPAs) and the response of the PCAOB to these issues, (3) issues involving conflicts between U.S. regulatory agencies and the Chinese government over access to audit-related documents, and (4) suggestions for future research.
\end{abstract}

Keywords: Auditing, Chinese reverse mergers, Public Company Accounting Oversight Board, Securities and Exchange Commission 


\section{Mll Macrothink}

International Journal of Accounting and Financial Reporting

ISSN 2162-3082

2012, Vol. 2, No. 2

\section{Introduction}

The purpose of this paper is to explore issues related to Chinese ${ }^{1}$ companies seeking capital in the United States (U. S.). The first issue is frauds that have been perpetrated by some companies using reverse mergers in order to go public. In recent years, a large number of Chinese companies have entered U. S. capital markets using reverse mergers. Some of these Chinese reverse mergers (CRM) have later been exposed as frauds. The second issue is fraud in continuing audit engagements when there has been reliance by an American audit firm on a foreign accountant's audit work. The Public Company Accounting Oversight Board (PCAOB) is charged with inspecting auditors' work but has been systematically thwarted in its attempt to examine the work of auditors of these companies in the People's Republic of China (PRC). These issues relate to characteristics of the practice of accounting and auditing in China that threaten auditor independence and audit quality (Yang et al. 2003). The next section provides background information about the practice of accounting and auditing in China. The remaining sections discuss: (1) issues involving reverse mergers and CRM and the response of the Securities and Exchange Commission (SEC) to these issues, (2) issues involving reliance on the work of foreign Certified Public Accountants (CPAs) and the response of the PCAOB to these issues, (3) issues involving conflicts between U.S. regulatory agencies and the PRC over access to audit-related documents, and (4) suggestions for future research.

\section{Characteristics of Chinese Accounting and Auditing}

There are two characteristics of the practice of accounting and auditing in China that threaten auditor independence and audit quality (Yang et al. 2003). The first is the relationship between the Chinese government and auditing firms. The second is the relationship between the Chinese government and the regulation of the Chinese accounting profession. These characteristics affect the ability of U. S. accounting firms to audit Chinese companies listed on U.S. stock exchanges as well as state-owned enterprises listed on Chinese stock exchanges.

The first Chinese CPA firm was established in 1981. Until 1998, the Chinese government required CPA firms to be formed only by government bodies or government- controlled institutions such as corporations and universities. These affiliated organizations exercised significant influence and control over Chinese CPA firms auditing Chinese companies, including setting policy and appointing personnel (Chen et al. 2005; Yang et al. 2001). However, government entities are the controlling shareholders in "virtually all listed companies and in the overwhelming majority of unlisted companies" (Yang et al. 2003, p. 59).

\footnotetext{
${ }^{1}$ We use the word "China" to refer to the People's Republic of China (PRC) and Hong Kong, which is a special administrative district of the PRC. The PCAOB, perhaps mindful of the political reality that the PRC regards Taiwan as a renegade province, states "the term 'China region' includes the People's Republic of China, Hong Kong Special Administrative Region, and Taiwan." (PCAOB 2010). We have been unable to locate any reference to frauds with CRM or failed audits originating with Taiwanese companies.
} 
This represents a potential conflict of interest. In addition, in some cases, government agencies had the authority to require businesses that they controlled to be audited by CPA firms that they controlled (Yang et al. 2003).

In 1993, the Chinese government promulgated a law reorganizing the CPA profession in China by allowing CPA firms to form either unlimited liability partnerships or limited liability corporations. This disaffiliation process was completed by 2000 (Chen et al. 2005). However, unlike limited liability partnerships in the U. S. where negligent partners' personal assets are still at risk, limited liability partnerships in China limit the liabilities of both non-negligent and negligent partners (Firth et al. 2012). There is also evidence that provincial regulators required or strongly encouraged CPA firms to adopt a "particular organizational form" and that CPA firms did not have a "completely free choice" in choosing between the two organizational forms at the time of disaffiliation (Firth et al. 2012, p. 11).

CPA firms in China are regulated by the Chinese Institute of Certified Public Accountants (CICPA) (Yang et al. 2003). However, CICPA is a government-controlled body and all of its decisions must be ratified by the Ministry of Finance (MOF). Chinese CPAs are only allowed to practice in firms, not individually; therefore, all Chinese CPAs are ultimately controlled by the central government. Initially, most Chinese CPA firms were small. However, in 2007, CICPA announced plans to develop ten large Chinese CPA firms that could compete internationally and 200 middle-sized firms to serve large domestic companies. The State Council of the PRC formally supported these plans in Document 56 which lays out the government's policies for the development of the accounting profession in China (Gillis 2010). In addition to having a practice license, Chinese CPA firms must also have a special license to audit listed companies (Firth et al. 2012). The MOF and the China Securities Regulatory Commission (CSRC) issue regulations about the required size for CPA firms. Recent rules which must be met by the end of 2013 require that an auditing firm have 80 million yuan in annual revenue (up from 16 million) and 200 CPAs (up from 80) to audit listed companies (Xin and Wee 2012). The State Council also directed the government to assist large Chinese CPA firms in expanding internationally by providing help with marketing, obtaining CPA qualifications in overseas countries, and diplomatic liaison and security (Gillis 2010). Document 56 also indicates that the MOF wants Chinese CPA firms to expand into the market for auditing large state-owned enterprises (SOEs) by telling these companies that they should "chose CPA firms that can protect the safety of national economic information" (Gillis 2010).

Partners in accounting firms in China must be Chinese CPAs. Because few foreign partners have become Chinese CPAs, when the Big Four were first given the right to audit in China in 1992, they were required to set up joint venture agreements with state-owned firms to audit Chinese companies (Chen et al. 2005). After the accounting profession in China was privatized, the joint ventures of the Big Four became CPA firms owned by local Chinese partners and managers (Gillis 2010). These operate "like a franchise" (China Briefing 2012). Most of these joint venture agreements will expire in 2012. The MOF, in Document 56, indicated that the joint ventures must be transferred into limited liability partnerships and that all partners must be Chinese CPAs (Gillis 2010). In March 2011, the MOF issued new rules 


\section{MInstitute Macrothink $_{\text {Int }}$}

International Journal of Accounting and Financial Reporting ISSN 2162-3082 2012, Vol. 2, No. 2

for foreign accounting firms that want to perform audit work in China for foreign clients. These rules require an application for a Temporary Audit Practice Certificate (TAPC) for each client identifying the client and providing various documents including copies of the CPA licenses of the foreign auditors coming to China. The foreign auditors must also agree to keep their working papers in China (Gorboski et al. 2011; Gillis 2011a).

The Big Four dominate the market for auditing larger Chinese companies. Smaller listed companies and companies resulting from reverse mergers have used smaller U. S. CPA firms. Although these firms are now required to obtain a TAPC for each client, six firms have set up a wholly foreign-owned Chinese subsidiary (WFOE). This was in response to the 2011 PCAOB Staff Audit Practice Alert No. 6 (PCAOB 2010) about the outsourcing of work to Chinese CPA firms. Although these firms are conducting audits in China, their offices are organized as consulting companies. In addition, only one of the firms has registered their WFOE with the PCAOB (Gillis 2011c). However, even if the remaining firms were to register with the $\mathrm{PCAOB}$, the Chinese government has refused to allow the PCAOB to conduct periodic inspections of registered firms (Gillis 2011b). The next section discusses reverse mergers, a "backdoor approach" (Gordon 2011), used by Chinese companies to raise capital in the U.S.

\section{Reverse Mergers}

Companies which seek to raise capital from the public in the U. S. must file extensive disclosure forms with the SEC. The cost of an initial public offering (IPO) can be well over $\$ 100,000$. Once public, a company must continuously report all material information in annual reports (Form 10-K), quarterly reports (Form 10-Q), material events reports (Form 8-K), and other reports. For many years, China has been accessing U.S. capital markets. In some cases, this has been through IPOs. In other cases, Chinese companies have gone public through "reverse mergers." In a reverse merger, private company shareholders acquire control of a "shell company." Part of the Nasdaq (2011a) definition of a shell company includes:

A company with no or nominal operations and either no or nominal assets, assets consisting solely of cash and cash equivalents, or assets consisting of any amount of cash and cash equivalents and nominal other assets is a "public shell".

The SEC (2011a) described the process of reverse mergers in a warning to investors about the danger of investing in these mergers. The private company shareholders exchange their shares for the shell company shares. The shell company is already registered with the SEC, so that the expensive and time-consuming process of an IPO is avoided. The private company shareholders can then put their own management into the shell company. The only SEC report that the shell company needs to file is a Form 8-K report to announce a major event. If the company is not registered to trade in the OTC market, then a Form 211 is filed with the Financial Industry Regulatory Authority. If the shell company is already trading in the OTC market, there is no need for even this form.

A reverse merger is attractive to a small business which cannot find financing, because this mechanism is fast than an IPO. The resulting public company may have greater access to 
capital markets (Stone 2008). The shareholders of the former private company now have a market which may be more liquid and their shares may sell at a higher premium. However, not all reverse mergers involve small companies. Ted Turner used this method to take Turner Broadcasting public and Muriel Siebert took her brokerage public by a reverse merger with a furniture company (Stone 2008). ValuJet became AirTran Airways through a reverse merger (AirTran 2011). A reverse merger may permit a company to avoid a change-of-control clause in a contract, as happened in the merger of Merck and Schering-Plough (Pollack 2009). The next section discusses reverse mergers used by Chinese companies to enter U.S. capital markets.

\section{Chinese Reverse Mergers}

The PCAOB (2011b) released a study of 159 public companies engaged in CRM in the period January 1, 2007 to March 31, 2010. In that time period, a total of 603 companies were engaged in reverse mergers; most of the 444 non-Chinese companies were American. The data in Table 1 indicate that the CRM companies had a combined market capitalization of $\$ 12.8$ billion, compared to a market capitalization of $\$ 27.2$ billion for the 56 Chinese companies which had an IPO in the same time period. While the market capitalization of the IPOs was more than twice as large as the CRM-companies, three times as many Chinese companies entered U. S. public markets through reverse mergers than through IPOs.

Table 1. CRM Auditors by Market Capitalization as of March 31, 2010.

\begin{tabular}{lllll}
\hline Firm Tier & $\begin{array}{l}\text { Number of } \\
\text { Companies }\end{array}$ & $\begin{array}{l}\text { Percentage } \\
\text { of } \\
\text { Companies }\end{array}$ & $\begin{array}{l}\text { Total Market } \\
\text { Capitalization } \\
\text { (in USD) }\end{array}$ & $\begin{array}{l}\text { Percentage of } \\
\text { Market } \\
\text { Capitalization }\end{array}$ \\
\hline $\begin{array}{l}\text { Annual } \\
\text { Inspection }\end{array}$ & 10 & $6 \%$ & $\$ 390$ & $3 \%$ \\
\hline $\begin{array}{l}\text { Triennial } \\
\text { Inspection }\end{array}$ & 147 & $94 \%$ & $\$ 12453$ & $97 \%$ \\
\hline Total & 157 & $100 \%$ & $\$ 12843$ & $100 \%$ \\
\hline
\end{tabular}

CRM Auditors by Market Capitalization are concentrated in small CPA firms.

(Source: PCAOB 2011b, p. 6, from Capital IQ. The PCAOB did not include two firms of the 159 firms because the two have stopped filing reports with the SEC.)

Nine of the 159 CRM companies were not listed on U.S securities exchanges; 150 CRM companies were listed on the following exchanges (PCAOB 2011b, p. 4): 
OTC Bulletin Board

Nasdaq

NYSE Euronext
101

34

15

$59 \%$ of the CRM companies reported revenue of $\$ 50$ million or less; these companies represented $17 \%$ of total assets.

Table 1 indicates that $94 \%$ of the auditors of the CRM companies were small U. S. CPA firms subject only to a triennial PCAOB inspection (PCAOB 2011, p. 6). In analyzing the audit firms for the CRM companies, the PCAOB noted that 24 CPA firms audited 70\% (110) of the CRM companies. "U.S. firms audited 116, or $74 \%$ of the CRM companies, and Chinese registered accounting firms audited 38 , or $24 \%$. Canadian registered accounting firms audited three CRM companies." (PCAOB 2011b, p. 6).

The next section discusses the response of the SEC to concerns of Nasdaq and the New York Stock Exchange (NYSE) that reverse mergers companies were manipulating their share prices to meet listing requirements (Myles 2011).

\subsection{SEC Actions Related to Chinese Reserve Mergers}

In 2011, the SEC formulated changes in rules for listing companies which have been in a reverse merger. This process was completed on November 9, 2011, when the SEC (2011b, 2011c) released new rules which barred companies involved in a reverse merger from being listed on the three major U. S. exchanges (NYSE, NYSE Amex and Nasdaq) until the company had traded on a U. S. OTC market or foreign exchange for one year and met minimum share price requirements (Myles 2011). This action was taken at the request of the three exchanges. Nasdaq stated "....that there have been widespread allegations of fraudulent behavior by Reverse Merger companies, leading to concerns that their financial statements cannot be relied upon." In addition, Nasdaq wrote that "...it appeared that promoters and others intended to manipulate prices of Reverse Merger companies' securities higher to help meet Nasdaq's initial listing bid price requirement, and where companies have gifted stock to artificially satisfy Nasdaq's public holder listing requirement." As a result of these complaints, companies will not be listed on Nasdaq unless they meet certain minimum price and longevity standards. The NYSE made a similar complaint and received the same relief (SEC 2011c). If these regulations are successful, then those CRM firms which do become listed in the future on Nasdaq and the NYSE will be more seasoned companies. However, Nasdaq (2011b) makes it clear that it welcomes listings by Chinese companies and has published a guide in both English and Chinese on how they might go public.

In early 2012, the SEC filed suit against three companies which had gone public through a CRM. The companies were Puda Coal, Inc. (SEC 2012a), Zhongpin, Inc. (SEC 2012b), and, AutoChina International Ltd (SEC 2012c). The SEC charged that insiders at Puda Coal looted the company. Chinese shareholders of Zhongpin were charged with insider trading. Autochina's CEO and relatives were charged with trading to boost share prices to find 


\section{$\triangle$ Macrothink}

International Journal of Accounting and Financial Reporting ISSN 2162-3082 2012, Vol. 2, No. 2

financing. In July 2012, SEC charged multiple individuals and entities in the U.S. for numerous violations of securities laws in connection with the CRM company, China Yingxia International, Inc. (SEC 2012d). The next section discusses the response of the PCAOB to allegations of irregularities in audits of Chinese companies.

\subsection{PCAOB Actions Related to Audits of Chinese Companies}

The annual report of a publicly-traded corporation must be audited by an independent CPA registered with the PCAOB. Among other responsibilities, the PCAOB is charged with setting audit standards for the registered accountants. The auditors registered with PCAOB must meet all the standards that non-registered CPAs do; these are education, experience, and successful passage of the CPA examination. Public company auditors registered with the PCAOB are inspected by PCAOB auditors. The large audit firms are inspected annually; other firms are inspected every three years (PCAOB 2011a). These inspections review the internal quality control of the CPA firm and the work papers which provide evidence of how the audit was conducted and support for the audit opinion. If there is a deficiency, the firm has 12 months to correct it; otherwise, the report is made public. If necessary, the PCAOB can suspend the firm and its individual members from auditing public companies.

The PCAOB has encountered many difficulties with auditors of CRM companies, described in Staff Audit Practice Alert No. 6 (PCAOB 2010). In general, the auditors of CRM companies do not appear to be following PCAOB standards. The Alert was written considering "... audit reports on financial statements filed by issuers that have substantially all of their operations outside of the U.S." The real target of this was the emerging recognition of abuse by Chinese firms, as stated in a footnote (PCAOB 2010, p. 2):

For example, in a 27-month period ending March 31, 2010, at least 40 U.S. registered public accounting firms with fewer than five partners and fewer than ten professional staff issued audit reports on financial statements filed with the SEC by companies whose operations were substantially all in the China region.

An example of a failed audit was when partners of a U.S. based CPA firm traveled to China, with no accompanying staff, and all of the audit work was performed by a local firm hired by the U.S. CPA firm. In the PCAOB's opinion, this violated AU Sec. 543, "Part of Audit Performed by Other Independent Auditors" (AICPA 1972) because the section “....does not provide a way for an auditor to take responsibility for the work of another auditor that has essentially audited an issuer's financial statements in their entirety...." (PCAOB 2010, p. 3). AU Sec. 543 refers to another auditor auditing "...subsidiaries, divisions, branches, components, or investments...," not taking responsibility of another auditor's audit of the entire entity. In another case, a U.S. firm exercised no adequate supervision; the firm essentially subcontracted the audit to a group of consultants. "None of the U.S. firm's partners or employees traveled to the China region or planned, performed, supervised, or meaningfully reviewed the audit work" (PCAOB 2010 p. 7). General auditing standards require that there be knowledge of the client and the industry. As the PCAOB stated, "The registered public accounting firm is responsible for planning the audit, and for ensuring that the work of assistants is supervised and reviewed in accordance with PCAOB standards" (PCAOB 2010, p. 9). Instead, there are instances of U.S. based CPA firms giving 
unqualified opinions on financial statements when no one from the U.S. firm planned the engagement, visited the foreign country, spoke the language, could verify the independence of the foreign auditor, could read the audit work papers or even knew whether or not there was sufficient evidence other than what was in English translations of the financial statements.

Not surprisingly, the PCOAB has been taking action to bar some accountants from practice. For example, for the 2003, 2004 and 2005 audits of PacificNet, Inc., Clancy and Co. CPAs were barred from practice before the PCAOB for one year (PCAOB 2009). One partner was personally suspended for two years and the managing partner was personally suspended for one year. Both partners were also suspended by the Arizona Board of Accountancy. In this case, the deficiency was that Clancy assumed responsibility for the work of a Hong Kong firm, even knowing that the audit work of the firm did not meet PCAOB standards and the accounting for material receivables and stock options was incorrect. PacificNet was delisted.

The SEC, the PCAOB, the CSRC, and the MOF met in July 2011 to attempt resolve the audit oversight issue. However, an agreement was not reached. The impetus for this meeting was the 24 securities fraud class-action suits (most on the grounds of accounting fraud) filed against Chinese reverse merger (CRM) companies during the first six months of 2011 (Bolger, 2011). These suits represented over $25 \%$ of the fraud class-action suits filed during that period of time (Gordon 2011). The problem with CRM is part of an international conflict between the PRC and the SEC and PCAOB over access to company documents and audit workpapers. This is illustrated by conflicts in which Deloitte Touche Tomatsu is currently involved.

\subsection{Conflicts between the PRC, the SEC and the PCAOB}

Deloitte Touche Tomatsu is currently caught in the conflict between the PRC and U. S. regulatory agencies. Deloitte audited Longtop Financial Technologies, a Chinese company. The company was delisted from the NYSE in 2011 amid allegations of fraud (Block 2012). Deloitte issued unqualified opinions for 2007-2010. In September, 2011, the SEC subpoenaed Deloitte's auditing records. Deloitte refused to produce the records because the CSRC in October 2011 warned the China offices of the Big Four not to give audit work papers to foreign regulators.

In May 2012, the SEC filed suit against Deloitte's Chinese affiliate for violation of the Sarbanes-Oxley Act for failing to turnover requested work papers. Deloitte says it cannot violate Chinese law. Ultimately, if the firm continues to refuse access to work papers, the SEC could suspend it from practice before the SEC. This affiliate audits over 40 public companies. Meanwhile, Deloitte states that it will spend \$160 million to expand its Chinese operations (McMahon and Hong 2012).

Some investors, looking for short-sale candidates, have taken the SEC filings of Chinese companies and compared them to local filings by the companies with the Chinese State Administration of Industry and Commerce (SAIC). In April 2012, the SAIC stopped access to those records, except for basic information such as the company's registered capital (McMahon 2012). This further decreases transparency. 
In May 2012, the MOF announced that the Big Four must put a Chinese national in charge of their Chinese audit operations by the end of the year (McMahon and Hong 2012). By the end of 2012, at least $60 \%$ of partners in Big Four firms in China must be Chinese CPAs, and by the end of 2017 , at least $80 \%$. Currently it is estimated that $90 \%$ of senior positions in CPA firms are held by non-Chinese (Gillis 2012).

The situation clearly calls for a diplomatic solution. Lewis H. Ferguson, member of the PCAOB, spoke in June 2012 in Shanghai about "a cooperative regime for cross-border auditing oversight" (PCAOB 2012). He spoke at length about the need for international cooperation on auditing oversight because firm operations and capital markets are global. The same problems appear in every country: overstatement of assets and earnings, problems with fair value measurements, going concern issues, the lack of professional skepticism, and "off balance-sheet structures." The PCAOB has conducted inspections in 38 non-U.S. jurisdictions, often in cooperation with local regulators.

Accounting failures of Chinese companies have consequences. Ferguson indicated that, "In the U.S. alone, 67 of these China-based issuers have either been delisted from U.S. securities exchanges or 'gone dark,' meaning they are no longer filing current reports with our SEC." For China to open itself to foreign regulators would be against its nationalism and xenophobia. Gillis (2012) believes “...it is China's intent to end the use of overseas stock markets by Chinese companies." China permitted companies to go overseas for capital but will be able to generate growth capital domestically in the future. The Chinese IPO market in the U.S. is already dead. If the SEC delists companies with Chinese auditors, then the companies likely will move to the Hong Kong Stock Exchange or go private. Gillis indicates that "many U.S. listed Chinese companies have already gone private, some with the financial backing of the State Council's China Development Bank." Meanwhile, it will take some time for the SEC to remove practice rights from Chinese firms. The scrutiny by the SEC of reverse mergers also means that Chinese firms will look for funding domestically, especially in Chinese OTC markets (Myles 2011). The next section discusses directions for future research.

\section{Recommendations}

The authors have recommendations involving research possibilities and government policy decisions.

\subsection{Recommendations for Research}

There are several possible research possibilities. One is to examine auditors, their fees, and consequences to audit firms of accepting the audit of a Chinese firm. Another possibility is the study of financial ratios of the companies which went public through CRM to see if it was possible to forecast a fraud, delisting, or both. A third possibility is to examine the political factors at work in the conflict between Chinese and U. S. agencies. At the moment, Chinese companies can either comply with the demands of the PCAOB and the SEC, and face sanctions by the Chinese government for revealing state secrets to a foreign government, or the companies can refuse to comply with the demands of the American regulators. In that case, they will likely be delisted. A fourth possibility for research is an analysis of the agency 
problem when the MOF controls who becomes a CPA in China and who belongs to a CPA firm in China, while the Chinese government also owns at least the $50 \%$ of all large companies in China.

\subsection{Recommendations for Government Policy}

The PCAOB and the SEC are vital parts of the American capital markets. The SEC states that its mission includes protection of investors and maintaining fair markets. Without trust in the capital markets, investors will not invest. The PCAOB's mission includes inspection of audit firms to be sure that auditors and their audit reports meet mandated standards. Presently, these two agencies are in conflict with audit firms in China. In section 4.1 we describe the SEC's confrontation with CRM companies who have misled investors with fraudulent financial statements. The authors believe that the SEC should continue its special enforcement action against the public companies involved in reverse mergers. As described in section 4.3, the SEC should continue its demands against auditors of Chinese companies and, if the auditors do not comply, suspend the auditors from doing work with SEC registrants.

The PCAOB has a more difficult challenge than the SEC. In section 4.2, we describe how the PCAOB has not been able to examine audit work papers held outside the U.S. While the SEC can take action against companies traded in the U.S., the PCAOB has no power over companies in other jurisdictions. We believe that the PCAOB's attempts to compromise with the MOF and CSRC were reasonable. We believe that it is unlikely that the secretive Chinese government will allow examination of the auditor work papers. The PCAOB should suspend audit firms which do not cooperate.

We believe that these steps are necessary to maintain the fairness of the U.S. financial reporting system. To do otherwise will impair confidence in U.S. capital markets.

\section{References}

American Institute of Certified Public Accountants. 1972. AU Section 543: Part of audit performed by other independent auditors. November.

AirTran Airways. 2011. AirTran Airways history. Available: http://www.airtranairways.com/about-us/history.aspx.

Block, Carson C. 2012. China's auditing train wreck. Wall Street Journal. May 3. Available: http://online.wsj.com/article/SB10001424052702304746604577381630586235646.html?KE YWORDS=china\%27s+auditing+train\#articleTabs\%3Darticle.

Bolger, Ryan. 2011. Regulator standoff on Chinese reverse mergers. International Financial Law Review. August 2011.2 Available: http://www.iflr.com/Article/2886245/Regulator-standoff-on-Chinese-reverse-mergers.html.

Chen, Shimin, Xijia Su , and Zhenglin Wang. 2005. An analysis of auditing environment and modified audit opinions in china: underlying reasons and lessons. International Journal of Auditing. 9 (3): 165-185.

China Briefing. 2012. 'Big Four' accounting firms face new regulatory challenges in China. 
Available: http://www.china-briefing.com/news/2012/03/02/.

Firth, Michael, Phyllis L. L. Mo, and Raymond M. K. Wong. 2012. Auditors' organizational form, legal liability, and reporting conservatism: evidence from China, Contemporary Accounting Research. 29 (1): 57-93.

Gillis, P. 2010. The perfect storm: big challenges face the Big Four in China. China Accounting

Blog.

Available:http://www.chinaaccountingblog.com/weblog/the-perfect-storm-big-chall.html.

Gillis, P. 2011a. Temporary audit practice certificates. China Accounting Blog. Available: http://www.chinaaccountingblog.com/weblog/temporary-audit-practice.html.

Gillis, P. 2011b. The nuclear option and the PCAOB. China Accounting Blog. Available: http://www.chinaaccountingblog.com/weblog/the-nuclear-option-and-the.html.

Gillis, P. 2011c. U.S. CPA firms in China. China Accounting Blog. Available: http://www.chinaaccountingblog.com/weblog/us-cpa-firms-in-china.html.

Gillis, P. 2012. Will the U.S. delist China stocks? Available: http://chinaaccountingblog.com/weblog/will-the-us-delist-chinese.html.

Gorbowski, J.V, Y. Li, and W. Yan. 2011. Tentative provisions on temporary auditing business carried out in mainland China by overseas accounting firms. Legal Update. http://www.faegrebd.com/13391.

Gordon, Leslie A. 2011. Red-flagging China. ABA Journal. 97 (10): 17-18.

McMahon, Dinny. 2012. Beijing dims the lights on data for investors. Wall Street Journal.

June

Available:

http://online.wsj.com/article/SB10001424052702303506404577448113933841708.

html?KEYWORDS=dinny+memahon.

McMahon, Dinny and Shen Hong. 2012. China wants local control of foreign auditing firms. Wall Street Journal. May 10. Available: http://online.wsj.com/article/ SB10001424052 702304203604577395423545473012.html?KEYWORDS=shen+hong.

Myles, Danielle and Lucy McNulty. 2011. SEC reverse merger rule's intentions queried. International Financial Law Review. Available: http://www.iflr.com/Article/2938983/SECreverse-merger-rules-intentions-queried.html.

Nasdaq. 2011a. Public Shells \& Business Combinations with Non-NASDAQ Entities

Resulting in a Change of Control. Available: https://listingcenter.nasdaqomx.com/Show_Doc.aspx? File=FAQsRevMerger.html.

2011b. Going Public: A Guide For Chinese Companies Listing On The U.S. Securities Markets. Available: https://listingcenter.nasdaqomx.com/Show_Doc.aspx?

File=china_listing_guide.html.

Pollack, Andrew. 2009. Taking a chance on a reverse merger. New York Times. March 9.

p. B4.

Public Company Accounting Oversight Board. 2009. In the Matter of Clancy and Co., 
P.L.L.C., Jennifer C. Nipp, CPA, and Judith J. Clancy, CPA. PCAOB Release No. 105-2009-001. March 31.

2010. Staff Audit Practice Alert No. 6: Auditor Considerations Regarding Using The Work Of Other Auditors And Engaging Assistants From Outside The Firm. Available: http://pcaobus.org/Standards/QandA/2010-07-12_APA_6.pdf. July 12.

------. 2011a. Firm Inspection Reports. Available:

http://pcaobus.org/Inspections/Reports/Pages/default.aspx.

--------. 2011b. Activity Summary and Audit Implications for Reverse Mergers Involving Companies from the China Region: January 1, 2007 through March 31, 2010. March 14. Research Note \#2011-P1. Available: http://pcaobus.org/Research/Documents/

Chinese_Reverse_Merger_Research_Note.pdf.

--------. 2012. Investor protection through audit oversight. Speech by Lewis H. Ferguson,

June

19.

Available:

http://pcaobus.org/News/Speech/Pages/06192012_FergusonSECConference.aspx .

Securities and Exchange Commission. 2011a. Investor Bulletin: Reverse Mergers.

Available: http://www.sec.gov/investor/alerts/reversemergers.pdf.

2011b. Notice and Order Granting Accelerated Approval to Proposed Rule Change, as Modified by Amendment No. 1, Adopting Additional Listing Requirements for Companies Applying to List After Consummation of a Reverse Merger With a Shell Company. Release 34-65708. November 9.

2011c. Notice and Order Granting Accelerated Approval to Proposed Rule Change, as Modified by Amendment No. 2, Amending Sections 102.01 and 103.01 of the Exchanges Listed Company Manual Adopting Additional Listing Requirements for Companies Applying to List After Consummation of a Reverse Merger With a Shell

Company. Release 34-65709. November 9.

-------. 2012a. SEC charges chairman and ex-CEO of Puda Coal with fraud. Litigation Release No. 22264. February 22.

2012b. SEC freezes accounts of six Chinese citizens and one offshore entity charged with insider trading. Litigation Release No. 22320. April 6.

-------. 2012c. SEC charges China-based company and others with stock manipulation. Litigation Release 22326. April 11.

2012d. SEC charges multiple individuals and entities in the U.S. for widespread misconduct in connection with Chinese reverse merger company. Litigation Release 22430. July 30 .

Stone, Ron. 2008. Reverse mergers can help attain liquidity, growth and capital goals California CPA Magazine. January/February. Available: http://www.calcpa.org/Content/24896.aspx

Yang, Lloyd, Q. Tang, A. Kilgore, and J. Y. Hong. 2001. Auditor-government associations and auditor independence in China. The British Accounting Review. 33 (2): 175-189. 


\section{Macrothink}

International Journal of Accounting and Financial Reporting

ISSN 2162-3082 2012, Vol. 2, No. 2

Yang, Lloyd, Alan Dunk, Alan Kilgore, Qingliang Tang, and Z. Jun Lin. 2003. Auditor independence issues in China. Managerial Finance. 29 (12): 57 - 64.

Xin, Zhou, and Sui-Lee Wee. 2012. China tightens rules for auditors of listed firms. Insurance Journal. Available: http://www.insurancejournal.com/news/international/ 2012/02/06/234237.htm.

\section{Copyright Disclaimer}

Copyright reserved by the author(s).

This article is an open-access article distributed under the terms and conditions of the Creative Commons Attribution license (http://creativecommons.org/licenses/by/3.0/). 